\title{
APPLICABILITY OF DESGINED TOOL TO ASSESS ENVIRONMENTAL RISKS FACTORS AFFECTED HOSPITALIZED PATIENTS IN PORTSAID CITY
}

\author{
Faten Ahmed Mohammed ${ }^{1}$;prof. SaharHamdy El-Said ${ }^{2} \&$ \\ prof. Sanaa Ibrahim Abdel-Azeem³ ${ }^{3}$ \& Dr. Marwa MohammedAbdel-Aleem ${ }^{4}$ \\ ${ }^{1}$ M.Sc., ${ }^{2,3}$ Professor, ${ }^{4}$ Lecturer Nursing AdministrationDepartment, Faculty of Nursing, \\ ${ }^{1,3,4}$ PortSaid University \& ${ }^{2}$ El-Zagazig University.
}

\begin{abstract}
Background: Environmental risk as the Probability value of an undesirable event and its consequences that arise from a spontaneous, natural origin or from a human action (physical or administrative) that is transmitted through the environment. The study aimedto test applicability of designed tool to assess environmental risk factors affect hospitalized patient in Port Said city. A methodological design was used for data collection.Setting:The study was conducted in Port Said General Hospital and El -Zohour Central Hospital. The study sample consists of three groups were; health team members (physician and nurses)( $n=260)$, Housekeepers $(n=39)$, andpatients $(n=60)$. Two tools were used for data collection; questionnaire sheet, and observational checklists.Results:The highly reliability coefficient was for the general work condition domain (0.969), while the lowest was for fire measures domain (0.453). The highest mean score of opinion about the importance of the environmental risk factors tool was among nurses, followed by physicians and the lowest mean score of opinion was among patients .Conclusion: The results demonstrated that the majority of environmental risk factors assessment tool where applicable, in inpatient units in two hospitals, while more applicable in El-Zohour Hospital than Port Said General Hospital. Recommendation: The environmental risk factors assessment tool should be provided for each department in health organization.
\end{abstract}

Keywords: Environment, Tool, Risk, Factors, Patients, Physician, Nurses. 


\section{INTRODUCTION}

Patient safety is one of the priorities of the Joint commission on accreditation of health care organizations and it has framed safety policies for the hospitals and healthcare facilities so that deaths due human error are completely eliminated (Landstad, 2016; Barnett \& Schuster 2018).According to Joint Commission on Accreditation of Healthcare Organizations (JCAHO), (2010)stated that a patient care initiative to make it necessary for the hospital to implement a caring, patient environment by establishing proper measures to prevent adverse effects on the health care workers, patients and visitors. The implementation of a proper measures and evaluation system makes it easy to avoid adverse and unexpected events like patient fall or other injuries during the intervention of patient treatment. Moreover, World Health Organization (WHO) (2010) estimated that tens of millions of patients worldwide suffer disabling injuries or death every year due to unsafe medical practices and care. Nearly one in ten patients is harmed while receiving health care in well-funded and technologically advanced hospital settings and bring additional medical expenses due to unsafe care, resulting in prolonged hospitalization, increase cost, disability and litigation. The word "environment" is broad and elastic in scope. Environment refers to external physical, chemical, and microbiological exposures and processes that impinge upon individuals and groups and are beyond the immediate control of individuals (Carayon and Alvarado, 2017; Clement, 2017).

Carayon and Alvarado (2017); Tweedy (2017) defined risk as a chance of loss will occur under the normal circumstances. It is a measure of harm or loss associated with an activity. As well Occupational Safety and Health Administration (2017) stated that there are a variety of risks associated with hospital facilities, involving physical factors in the unit environment, as floors, heating and ventilation, lighting, patient's room, storage rooms, medical gas system, electrical facilities, and fire protection facilities.

Risk assessment is considered as the initial and periodical step in a risk management process. It is the determination of quantitative or qualitative value of risk related to a concrete situation and a recognized threat. It may be the most important step in the risk management process, and may also be the most difficult and prone to error. 
Once risks have been identified and assessed, the steps to properly deal with them are much more programmatically (Gaber, 2009; Lerche, 2016).

In this respect, Yoder-Wise(2017) mentioned that Facility safety depends on the use of appropriate equipment and preventive maintenance and repair. Providing a hazard free environment for patients is the shared responsibility of all health care workers and awareness of safety and health issues is the key to accident prevention (Rogers, 2012).

\section{AIM OF STUDY:}

The aim of this study is to test applicability of designing tool to assess environmental risk factors affecting hospitalized patients in Port Said City through:

1. Assess opinion of health team about importance of environmental risk factors tool

2. Test applicability of the proposed tool.

\section{SUBJECTS AND METHODS:}

\section{(I) TECHNICAL DESIGN:}

\section{Research design:-}

A methodological research design was used to apply a tool toassess environmental risk factors affecting hospitalized patient in Port Said City.

\section{Settings:}

This study was conducted at all inpatient units at Port Said General Hospital, and ElZohuor Hospital, which affiliated to the Ministry of Health in Port Said City

\section{Subjects}

Three groups of subjects were included in the study

\section{First group: Health team members:}


All available physicians and nurses who working at inpatient unit during the time of the study. The total number of health team member was 260 of which 81 physicians and 140 nurses.

\section{Second group: Housekeepers:}

All housekeepers working in inpatient units were included in the study with total number $(\mathrm{n}=39)$.

\section{Third group: patients:}

A convenience sample of 60 patients who admitted in inpatient units in the above mention settings with the inclusion criteria

-Adult, conscious and able to communicatepatient.

- Stay at least 3 days in the hospital.

\section{TOOLS FOR DATA COLLECTION:}

Two tools were used to collect data for this study.

TOOL (I):Questionnaire sheet was developed by the researcher based on relevant literature review (OSHA, 2009; CDC, 2010; Burden \& Quinn, 2010; Abo-El Hassan, 2011; JCAOHCO, 2012; George, 2015; The Association for Professional in Infection Control and Epidemiology (APIC), 2015). To determine the importance of the tool dimensions and its sub items from the viewpoint of physicians, nurses, housekeepers, and patients.

\section{This tool consisted of two main parts as follows:}

\section{Part I:}

This part was intended to collect data related to personal characteristics of the participants including age, gender, marital status, educational level, years of experience, workplace, and job position for health team members only.

\section{Part II:}

This part concerned with participant's agreement upon, the importance of tool for environmental risk factors. It consists of 278 items grouped under 21 dimensions; human resources( six items), education and training (20 items), housekeeping (nine items) general work conditions (24 items), ventilation (seven items), lighting and electricity (11 items), food (20 items), water supply (seven items), furniture \& 
equipment (13 items), material handling \& storing (12 items), maintenance (seven items), protect patient from falling (17 items), protect patient from bed sores (10 items), disaster and crises (six items), fire (14 items), waste disposal (16items), infection control (21items), basic principles of infection control when dealing with linens and furnishings (seven items), medication error (22 items), general safety rules (18 items), and risk management (11 items).

\section{Scoring system:}

Subjects' responses were measured at three points Likert scale. Responses to these items were scored from 3 (important), 2 (uncertain), and one (not important).

TOOL (II): Observational Checklist was developed by the researcher based on the relevant literature review. It's based on the questionnaire sheets to determine the applicability of the developed assessment, environmental risk factors tool' items in inpatient units. It consists of two parts:

Part (I): This part was intended to collect data related to the unit's name, date of observation, and the time of observation.

Part (II): This part consists of 278 items grouped under the same 21dimensions of the questionnaire sheet.

\section{Scoring system:}

The responses were yes and no, two scores for yes, and one for no, the total score was calculated .

\section{(II) OPERATIONAL DESIGN:}

The operational design for this study included three stages; preparatory stage, pilot study and fieldwork.

Phase (I) preparatory stage

This step aimed at confirming the tool validity by conduct constructs validity using factor analysis approach. Items analysis was used to assess the internal consistency of the instrument which reflected in the value of Cronbach's alpha coefficient.

\section{Phase (II): Pilot study (4 month period)}

A pilot study was carried out after designing the environmental risk factors tool. It was carried out before starting field work and data collection. The aim of the pilot study was examining the clarity of language and feasibility of the environmental risk factors tool and to identify the obstacles and problems that may be encountered while 
data collection, and determine the applicability of the tool. In addition to estimate the time needed to complete the tools forms.

The pilot study was conducted on 8 physicians, 14nurses, 4 housekeepers, and6 patients selected randomly from inpatient units at Port Said General Hospital and ElZohour Hospital. In the light of the finding of the pilot study, the tool was modified and put in the final forms . All of these subjects were excluded from the main study sample.

\section{Phase (III):Field work}

\section{Distribution of questionnaire sheets:}

The questionnaire sheets were distributed to the health team members, housekeepers, and selected (60) patients in inpatient units at Port Said General Hospital and El Zohour Hospital for identifying the importance of the tool. The components of the questionnaire sheets and study aim were explained to the participants; they were reassured that the information collected would be used for scientific research only and would be confidential and they had the choice to put their names on the sheets or not. They were filled at the time of distribution. Filling of the questionnaire form took about 60 minutes. The researcher checked each questionnaire after the participant completed it to check any missing information.

\section{Application of the developed tool}

The developed tool (Observational checklist sheet) was filled out by the researcher during day duty. Filling out observation checklist for every unit took about 60 minutes during morning and evening shifts. This phase took about three months duration (the researcher spent nine days in each unit.

\section{(III) ADMINISTRATIVE DESIGN}

Before starting any step in the study, an official letter was obtained from the Dean of the Faculty of Nursing, Port Said University, to the Director of both Hospitals, for permission and cooperation to conduct the study.

\section{(IV) STATISTICAL DESIGN:}

Upon completion of data collection, data were revised, coded and entered using the PC. Data entry and statistical analysis were fulfilled using the statistical package for 
social sciences(SPSS) package version 20.0. (Armonk, NY: IBM Corp). Data were presented using descriptive statistics in the form of frequencies, percentages, mean and standard deviations for quantitative variables. And the X2 Test square test was used for comparisons between qualitative variables, Cronbach's alpha was used for consistency reliability of the tool.

- Statistical significance was considered at p-value $<0.05$.

1- Student t-test: For normally distributed quantitative variables, to compare between two studied groups

2 - F-test (ANOVA): For normally distributed quantitative variables, to comparisons between more than two groups

\section{RESULTS:}

Table(1): The personal and job characteristics of health team members and housekeepers illustrated in table (1). Regarding age, the highest percentages of physicians and housekeepers were in the age group range from 40 to 49 years old (43.2\% \& 66.7 respectively), while the highest percentages of nurses were in the age group range from 20 to 29 years old (49.3\%). The highest percentages of nurses and housekeepers were female ( $92.1 \%$ \& 69.2\%, respectively), while male percent among physicianslevels $67.9 \%$. As regards educational qualification, the highest percentages of nurses and housekeepers had a diploma degree (57.9\% \&74.4\%, respectively), while the majority of physicians had a postgraduate degree $(87.7 \%)$. About half of physicians had more and equal fifteen years of experience (51.9\%), about one third of nurses had years of experience range from five to less than ten years, while one third of housekeepers had less than five years of experience ( $31.4 \% \& 38.5 \%$ respectively).

Table (2): shows that the highest mean percent score of opinion was among nurses $(95.29 \pm 5.52)$, followed by physicians $(94.27 \pm 5.34)$, and the lowest mean percent score opinion was among patients $(83.02 \pm 14.45)$. There was a statistical significant difference between opinions of all study subjects $(\mathrm{f}=36.583 \& \mathrm{p}=<0.001)$

Table (3): shows opinion scores of physicians and nurses regarding the importance of environmental risk tool subscales. It's clear from the table the highest mean percent scores of agreement of physician and nurses were related to general work condition $(68.09 \pm 5.33 \& 70.19 \pm 3.88$ respectively), while the lowest mean scores was related to 
human resources \&disaster management subscales $(15.74 \pm 1.84,17.59 \pm 1.14,16$. $94 \pm 1.67 \& 17.39 \pm 1.39$, respectively).

Table (4-5): shows mean percent score of environmental risks factors tool subscales as observed in the study hospitals. It is cleared from the table the highest mean score of the application of environmental risks factors tool subscales was in Zohour hospital than in Port Said General hospital (75.72 $\pm 5.88 \& 66.26 \pm 5.47$, respectively), with a statisticallysignificant difference between the two hospitals $(\mathrm{p}=0.001)$

Table (1): Personal and job characteristics of health team members and housekeepers $(\mathrm{N}=260)$

\begin{tabular}{|c|c|c|c|c|c|c|}
\hline \multirow[t]{2}{*}{ |Personal and job characteristics } & \multicolumn{2}{|c|}{$\begin{array}{l}\text { Physicians } \\
(\mathrm{N}=81)\end{array}$} & \multicolumn{2}{|c|}{$\begin{array}{l}\text { Nurses } \\
(\mathrm{N}=140)\end{array}$} & \multicolumn{2}{|c|}{$\begin{array}{l}\text { Housekeepers } \\
(\mathrm{N}=39)\end{array}$} \\
\hline & No. & $\%$ & No. & $\%$ & No. & $\%$ \\
\hline \multicolumn{7}{|l|}{ Age } \\
\hline $20-29$ & 6 & 7.4 & 69 & 49.3 & 0 & 0.0 \\
\hline $30-39$ & 22 & 27.2 & 54 & 38.6 & 5 & 12.8 \\
\hline $40-49$ & 35 & 43.2 & 17 & 12.1 & 26 & 66.7 \\
\hline$\geq 50$ & 18 & 22.2 & 0 & 0.0 & 8 & 20.5 \\
\hline Min. - Max. & \multirow{2}{*}{\multicolumn{2}{|c|}{$\begin{array}{l}23.0-55.0 \\
42.11 \pm 8.29\end{array}$}} & \multirow{2}{*}{\multicolumn{2}{|c|}{$\begin{array}{l}20.0-49.0 \\
31.0 \pm 6.52\end{array}$}} & \multirow{2}{*}{\multicolumn{2}{|c|}{$\begin{array}{l}30.0-55.0 \\
44.31 \pm 6.69\end{array}$}} \\
\hline Mean \pm SD. & & & & & & \\
\hline \multicolumn{7}{|l|}{ Gender } \\
\hline Male & 55 & 67.9 & 11 & 7.9 & 12 & 30.8 \\
\hline Female & 26 & 32.1 & 129 & 92.1 & 27 & 69.2 \\
\hline \multicolumn{7}{|l|}{ Hospital } \\
\hline -El-Zohoor hospital & 40 & 49.4 & 70 & 50.0 & 19 & 48.7 \\
\hline -Port said general hospital & 41 & 50.6 & 70 & 50.0 & 20 & 51.3 \\
\hline \multicolumn{7}{|l|}{ Unit } \\
\hline Medical & 13 & 16.0 & 13 & 9.3 & 4 & 10.3 \\
\hline Orthopedic & 6 & 7.4 & 9 & 6.4 & 2 & 5.1 \\
\hline Surgical & 11 & 13.6 & 11 & 7.9 & 5 & 12.8 \\
\hline ICU & 16 & 19.8 & 41 & 29.3 & 7 & 17.9 \\
\hline CUU & 12 & 14.8 & 21 & 15.0 & 8 & 20.5 \\
\hline Male medical & 4 & 4.9 & 7 & 5.0 & 1 & 2.6 \\
\hline Female medical & 5 & 6.2 & 11 & 7.9 & 2 & 5.1 \\
\hline Dialysis & 5 & 6.2 & 16 & 11.4 & 4 & 10.3 \\
\hline Obstetric & 4 & 4.9 & 6 & 4.3 & 4 & 10.3 \\
\hline Burn & 5 & 6.2 & 5 & 3.6 & 2 & 5.1 \\
\hline \multicolumn{7}{|l|}{ Education level } \\
\hline Diploma & 0 & 0.0 & 81 & 57.9 & 29 & 74.4 \\
\hline Technical institute & 0 & 0.0 & 30 & 21.4 & 10 & 25.6 \\
\hline Bachelor's degree & 10 & 12.3 & 23 & 16.4 & 0 & 0.0 \\
\hline Master degree & 45 & 55.6 & 6 & 4.3 & 0 & 0.0 \\
\hline Doctorate degree & 26 & 32.1 & 0 & 0.0 & 0 & 0.0 \\
\hline Years of experience & & & & & & \\
\hline
\end{tabular}




\begin{tabular}{||l|l|l|l|l|l|l||}
$<5$ & 26 & 32.1 & 42 & 30.0 & 15 & 38.5 \\
$5-<10$ & 0 & 0.0 & 44 & 31.4 & 11 & 28.2 \\
$10-<15$ & 13 & 16.0 & 37 & 26.4 & 7 & 17.9 \\
$\geq 15$ & 42 & 51.9 & 17 & 12.1 & 6 & 15.4 \\
\hline Min. - Max. & $4.0-28.0$ & $1.0-32.0$ & $2.0-18.0$ \\
Mean \pm SD. & $13.43 \pm 7.86$ & $9.07 \pm 7.14$ & $7.87 \pm 5.60$ \\
\hline
\end{tabular}

Table (2): Total opinion mean percent scores of health team members, housekeepers \& patients about importance of environmental risk factors tool $(\mathrm{N}=320)$

\begin{tabular}{|c|c|c|c|c|c|c|}
\hline \multirow[b]{2}{*}{ Overall } & \multicolumn{3}{|l|}{ Health teams } & \multirow[b]{2}{*}{$\begin{array}{l}\text { Patients } \\
(\mathbf{n}=60)\end{array}$} & \multirow[b]{2}{*}{$\mathbf{F}$} & \multirow[b]{2}{*}{$\mathbf{P}$} \\
\hline & $\begin{array}{l}\text { Physicians } \\
(\mathbf{n = 8 1})\end{array}$ & Nurses $(n=140)$ & $\begin{array}{l}\text { Housekeepers } \\
(n=39)\end{array}$ & & & \\
\hline $\begin{array}{l}\text { Total score } \\
\text { percent score }\end{array}$ & $\begin{array}{l}802.15 \pm 29.68 \\
94.27 \pm 5.34\end{array}$ & $\begin{array}{l}807.80 \pm 30.69 \\
95.29 \pm 5.52\end{array}$ & $\begin{array}{l}68.26 \pm 5.08 \\
86.51 \pm 10.16\end{array}$ & $\begin{array}{l}143.67 \pm 15.60 \\
83.02 \pm 14.45\end{array}$ & $36.583^{*}$ & $<0.001^{*}$ \\
\hline
\end{tabular}

$F, p: F$ and $p$ values for ANOVAtest

$*$ : Statistically significant at $p \leq 0.05$

Table (3): Opinion scores of physicians and nurses regarding the importance of the environmental risk tool subscales $(\mathrm{N}=221)$

\begin{tabular}{||l|l|l|l|l||}
\hline \hline Tool dimensions & $\begin{array}{l}\text { Physicians } \\
(\mathbf{n = 8 1 )}\end{array}$ & $\begin{array}{l}\text { Nurses } \\
(\mathbf{n = 1 4 0})\end{array}$ & T test & $\begin{array}{l}\text { P } \\
\text { value }\end{array}$ \\
\hline - Human resources & $15.74 \pm 1.84$ & $17.59 \pm 1.14$ & 8.190 & $<0.001^{*}$ \\
\hline - Education and training & $56.98 \pm 3.91$ & $57.80 \pm 3.64$ & 1.579 & 0.116 \\
\hline - General work condition & $68.09 \pm 5.33$ & $70.19 \pm 3.88$ & 3.102 & 0.002 \\
\hline - Ventilation & $20.37 \pm 1.27$ & $20.68 \pm 0.95$ & 1.901 & 0.060 \\
\hline - Lightning & $31.89 \pm 1.72$ & $31.99 \pm 1.95$ & 0.399 & 0.690 \\
\hline - Furniture and equipment & $37.60 \pm 1.81$ & $37.40 \pm 2.72$ & 0.671 & 0.503 \\
\hline - Material handling and storing & $34.67 \pm 2.14$ & $35.13 \pm 2.19$ & 1.524 & 0.129 \\
\hline - Maintenance & $20.53 \pm 1.17$ & $20.18 \pm 1.75$ & 1.786 & 0.076 \\
\hline - Disasters and crises & $16.94 \pm 1.67$ & $17.39 \pm 1.39$ & 2.070 & 0.040 \\
\hline - Dealing with fire & $41.12 \pm 1.87$ & $41.06 \pm 2.13$ & 0.208 & 0.835 \\
\hline - Infection control & $61.69 \pm 2.04$ & $61.08 \pm 3.11$ & 1.765 & 0.078 \\
\hline - Medication errors avoidance & $64.27 \pm 2.90$ & $63.46 \pm 4.31$ & 1.675 & 0.095 \\
\hline$\bullet$ General safety rules & $53.20 \pm 1.58$ & $51.93 \pm 3.03$ & 4.082 & $<0.001^{*}$ \\
\hline$\bullet$ Risk management & $31.94 \pm 1.68$ & $32.14 \pm 1.82$ & .797 & 0.426 \\
\hline
\end{tabular}


Table (4): Mean score of application of environmental risks factors tool subscales in the study hospitals

\begin{tabular}{|c|c|c|c|c|}
\hline \multirow{2}{*}{ Tool subscales } & \multicolumn{2}{|l|}{ Hospital } & \multirow{2}{*}{ P value } & \multirow{2}{*}{ Total } \\
\hline & Zohor & El Amery & & \\
\hline $\begin{array}{l}\text { Human resources } \\
\text { Total score } \\
\% \text { score }\end{array}$ & $\begin{array}{l}3.89 \pm 0.69 \\
64.81 \pm 11.44\end{array}$ & $\begin{array}{l}3.81 \pm 1.17 \\
63.42 \pm 19.46\end{array}$ & 0.833 & $\begin{array}{l}3.85 \pm 0.94 \\
64.12 \pm 15.63\end{array}$ \\
\hline $\begin{array}{l}\text { Education and training } \\
\text { Total score } \\
\% \text { score } \\
\end{array}$ & $\begin{array}{l}18.39 \pm 2.76 \\
91.94 \pm 13.81\end{array}$ & $\begin{array}{l}16.03 \pm 2.23 \\
80.14 \pm 11.13\end{array}$ & $0.031^{*}$ & $\begin{array}{l}17.21 \pm 2.73 \\
86.04 \pm 13.67\end{array}$ \\
\hline \begin{tabular}{|l} 
Housekeeping \\
Total score \\
$\%$ score \\
\end{tabular} & $\begin{array}{l}8.17 \pm 1.10 \\
90.74 \pm 12.18\end{array}$ & $\begin{array}{l}6.08 \pm 1.23 \\
67.59 \pm 13.69 \\
\end{array}$ & $<0.001^{*}$ & $\begin{array}{l}7.12 \pm 1.56 \\
79.17 \pm 17.33\end{array}$ \\
\hline \begin{tabular}{|l} 
General work conditions \\
Total score \\
$\%$ score \\
\end{tabular} & $\begin{array}{l}16.25 \pm 2.54 \\
67.71 \pm 10.60\end{array}$ & $\begin{array}{l}11.31 \pm 3.35 \\
47.11 \pm 13.97\end{array}$ & $0.001^{*}$ & $\begin{array}{l}13.78 \pm 3.85 \\
57.41 \pm 16.05\end{array}$ \\
\hline \begin{tabular}{|l} 
Ventilations \\
Total score \\
$\%$ score
\end{tabular} & $\begin{array}{l}6.39 \pm 0.87 \\
91.27 \pm 12.49\end{array}$ & $\begin{array}{l}3.69 \pm 1.17 \\
52.78 \pm 16.68\end{array}$ & $<0.001^{*}$ & \begin{tabular}{|l}
$5.04 \pm 1.71$ \\
$72.02 \pm 24.37$
\end{tabular} \\
\hline $\begin{array}{l}\text { Lighting and electricity } \\
\text { Total score } \\
\% \text { score } \\
\end{array}$ & $\begin{array}{l}9.61 \pm 1.32 \\
87.37 \pm 11.97\end{array}$ & $\begin{array}{l}7.92 \pm 2.16 \\
71.97 \pm 19.64\end{array}$ & $0.030^{*}$ & $\begin{array}{l}8.76 \pm 1.95 \\
79.67 \pm 17.75\end{array}$ \\
\hline \begin{tabular}{|l} 
Food \\
A-Kitchen design \\
Total score \\
$\%$ score \\
\end{tabular} & $\begin{array}{l}10.81 \pm 1.22 \\
90.05 \pm 10.15\end{array}$ & $\begin{array}{l}6.94 \pm 2.18 \\
58.56 \pm 17.67 \\
\end{array}$ & $<0.001^{*}$ & $\begin{array}{l}8.88 \pm 2.62 \\
74.31 \pm 21.38 \\
\end{array}$ \\
\hline \begin{tabular}{|l|} 
B-Food cooking \\
Total score \\
$\%$ score \\
\end{tabular} & \begin{tabular}{|l}
$6.64 \pm 1.00$ \\
$82.99 \pm 12.49$
\end{tabular} & $\begin{array}{l}5.31 \pm 1.36 \\
66.32 \pm 16.99 \\
\end{array}$ & $0.012^{*}$ & $\begin{array}{l}5.97 \pm 1.35 \\
74.65 \pm 16.89\end{array}$ \\
\hline \begin{tabular}{|l|} 
Water \\
Total score \\
$\%$ score \\
\end{tabular} & \begin{tabular}{|l}
$5.75 \pm 2.05$ \\
$82.14 \pm 29.22$
\end{tabular} & $\begin{array}{l}4.03 \pm 1.13 \\
57.54 \pm 16.17\end{array}$ & $0.018^{*}$ & $\begin{array}{l}4.89 \pm 1.84 \\
69.84 \pm 26.30\end{array}$ \\
\hline $\begin{array}{l}\text { Furniture and equipment } \\
\text { Total score } \\
\% \text { score }\end{array}$ & $\begin{array}{l}9.11 \pm 2.41 \\
70.09 \pm 18.57\end{array}$ & $\begin{array}{l}8.14 \pm 1.60 \\
62.61 \pm 12.34\end{array}$ & 0.258 & $\begin{array}{l}8.63 \pm 2.06 \\
66.35 \pm 15.88\end{array}$ \\
\hline \begin{tabular}{|l|} 
Material handling and storing \\
Total score \\
$\%$ score \\
\end{tabular} & $\begin{array}{l}9.86 \pm 1.70 \\
82.18 \pm 14.14 \\
\end{array}$ & $\begin{array}{l}9.39 \pm 1.62 \\
78.24 \pm 13.50 \\
\end{array}$ & 0.493 & $\begin{array}{l}9.63 \pm 1.64 \\
80.21 \pm 13.66 \\
\end{array}$ \\
\hline \begin{tabular}{|c|} 
Maintenance \\
Total score \\
$\%$ score \\
\end{tabular} & \begin{tabular}{|l}
$5.08 \pm 1.31$ \\
$72.62 \pm 18.73$
\end{tabular} & $\begin{array}{l}3.92 \pm 0.73 \\
55.95 \pm 10.38\end{array}$ & $0.015^{*}$ & $\begin{array}{l}4.50 \pm 1.20 \\
64.28 \pm 17.08\end{array}$ \\
\hline \begin{tabular}{|l|} 
Protect patient's from falling \\
Total score \\
$\%$ score \\
\end{tabular} & $\begin{array}{l}11.17 \pm 2.36 \\
65.69 \pm 13.90\end{array}$ & $\begin{array}{l}9.28 \pm 2.13 \\
54.58 \pm 12.54 \\
\end{array}$ & 0.052 & $\begin{array}{l}10.22 \pm 2.40 \\
60.13 \pm 14.14 \\
\end{array}$ \\
\hline
\end{tabular}

p: $p$ value for Student t-test for comparing between the two hospitals

*: Statistically significant at $\mathrm{p} \leq 0.05$ 
Cont... Table (5): Mean score of application of environmental risks factors tool subscales in the study hospitals

\begin{tabular}{|c|c|c|c|c|}
\hline \multirow{2}{*}{ Items } & \multicolumn{2}{|l|}{ Hospital } & \multirow[b]{2}{*}{ p } & \multirow{2}{*}{ Total } \\
\hline & Zohor & El Amery & & \\
\hline \multicolumn{5}{|c|}{ Protect patient from bed sores } \\
\hline Total score & $7.67 \pm 1.26$ & $5.0 \pm 2.23$ & \multirow{2}{*}{$0.002^{*}$} & $6.33 \pm 2.23$ \\
\hline$\%$ score & $76.67 \pm 12.55$ & $50.0 \pm 22.29$ & & $63.33 \pm 22.33$ \\
\hline \multicolumn{5}{|c|}{ Disaster and crises } \\
\hline Total score & $4.94 \pm 1.40$ & $4.36 \pm 1.47$ & \multirow{2}{*}{0.331} & $4.65 \pm 1.44$ \\
\hline$\%$ score & $82.41 \pm 23.31$ & $72.68 \pm 24.56$ & & $77.55 \pm 23.94$ \\
\hline \multicolumn{5}{|l|}{ Fire } \\
\hline Total score & $10.64 \pm 1.54$ & $11.17 \pm 1.26$ & \multirow{2}{*}{0.368} & $10.90 \pm 1.40$ \\
\hline$\%$ score & $75.99 \pm 11.0$ & $79.76 \pm 9.0$ & & $77.88 \pm 10.01$ \\
\hline \multicolumn{5}{|c|}{ Waste Disposal } \\
\hline Total score & $14.03 \pm 3.35$ & $14.44 \pm 1.09$ & \multirow{2}{*}{0.688} & $14.24 \pm 2.44$ \\
\hline$\%$ score & $87.67 \pm 20.92$ & $90.28 \pm 6.84$ & & $88.98 \pm 15.28$ \\
\hline \multicolumn{5}{|c|}{ Infection control } \\
\hline Total score & $14.67 \pm 4.23$ & $13.50 \pm 2.29$ & \multirow{2}{*}{0.412} & $14.08 \pm 3.38$ \\
\hline$\%$ score & $73.33 \pm 21.14$ & $67.50 \pm 11.43$ & & $70.42 \pm 16.88$ \\
\hline \multirow{3}{*}{\multicolumn{5}{|c|}{$\begin{array}{l}\text { Basic principles of infection control } \\
\text { when dealing with linens and } \\
\text { furnishings }\end{array}$}} \\
\hline & & & & \\
\hline & & & & \\
\hline Total score & $5.75 \pm 1.32$ & $4.25 \pm 0.88$ & \multirow{2}{*}{$0.003^{*}$} & $5.0 \pm 1.34$ \\
\hline$\%$ score & $82.14 \pm 18.84$ & $60.71 \pm 12.54$ & & $71.43 \pm 19.10$ \\
\hline \multicolumn{5}{|c|}{ Medication error } \\
\hline Total score & $6.97 \pm 3.16$ & $14.39 \pm 2.66$ & \multirow{2}{*}{$<0.001^{*}$} & $10.68 \pm 4.74$ \\
\hline$\%$ score & $31.69 \pm 14.37$ & $65.40 \pm 12.08$ & & $48.55 \pm 21.56$ \\
\hline \multicolumn{5}{|c|}{ General Safety Rules } \\
\hline Total score & $14.56 \pm 2.20$ & $12.17 \pm 2.80$ & \multirow{2}{*}{$0.030^{*}$} & $13.36 \pm 2.75$ \\
\hline$\%$ score & $80.86 \pm 12.24$ & $67.59 \pm 15.56$ & & $74.23 \pm 15.28$ \\
\hline \multicolumn{5}{|c|}{ Risk management } \\
\hline Total score & $9.42 \pm 2.73$ & $8.42 \pm 1.78$ & \multirow{2}{*}{0.300} & $8.92 \pm 2.31$ \\
\hline$\%$ score & $52.31 \pm 15.17$ & $46.76 \pm 9.90$ & & $49.54 \pm 12.84$ \\
\hline \multicolumn{5}{|l|}{ Overall } \\
\hline Total score & $209.75 \pm 16.29$ & $183.53 \pm 15.16$ & \multirow{2}{*}{$<0.001^{*}$} & $196.64 \pm 20.40$ \\
\hline$\%$ score & $75.72 \pm 5.88$ & $66.26 \pm 5.47$ & & $70.99 \pm 7.37$ \\
\hline
\end{tabular}

$\mathrm{p}$ : $\mathrm{p}$ value for Student t-test for comparing between the two hospitals

*: Statistically significant at $\mathrm{p} \leq 0.05$ 


\section{DISCUSSION:}

Hospital environments present especial conditions derived from specific activities developed in these areas and also from individual characteristics observed among the users of these facilities, thus the hospital environment plays an important role in hospital acquired infection (Straub et al., 2013).

The environment in which care is provided can make difference. Numerous studies demonstrate that factors in the physical and social environment can impact patients for better or worse. Physical Environment and Technology/Specialization were themes emphasized as contributing to increased risk inpatient care (Lerche, 2016).

The main responsibility for the working environment devolves on the organization. All measures needed must take to prevent the exposure of the patient to the risk of the environment. One of the basic principles of the employer's preventive activity must be for everything dangerous to be altered or replaced to eliminate the risk. This also implies that, if the risk cannot be fully eliminated, the employer must instead take steps to reduce it (Carayon and Alvarado, 2017).

The aim of the present study was assess environmental risk factors affecting hospitalized patients in Port Said City.

\section{Personal and job characteristics of physicians, nurses, housekeepers and patients}

The findings of the current study reveal that the highest percentage of the studied sample was staff nurses, while the lowest percentage was from the housekeepers. Near from the half of physicians and more than half of housekeeper were in the age group from forty to less than fifty years old, while about half of nurses more in the age group range from twenty to less than thirty years old. The highest percentage of nurses and housekeepers are female,while are male among physician groups.

Regarding the educational level, the finding of the present study reveals that the highest percentage of nurses and housekeepers had diploma degree, while more than half of physician had master degree. Slightly more than half of physician had more than an equal fifteen years of experience, while one third of nurses had five to less than ten 
years of experience and one third of housekeepers had less than five years of experience.

Regarding Health team members, patients and housekeepers' opinions about the importance of environmental risk factors tool .The findings of the current study reveal that the highest percentage of health team members \&patients were agreed upon the environmental risk factorsdimensions and its sub items, while the nurses were the highest agreement followed by doctors then housekeepers and the lowest was patients. This may be due to the nurses spent more time with patients and considered the most health team member aware with environmental risk affecting patient as human resources, ventilation, water, furniture, equipment, maintenance, and waste disposable. These findings were agreed with the study of Abu Saileek (2010) who found that the majority of staff nurses agreed upon the importance of the environmental risk factors tool. Also the study carried out in California by Joseph (2016) who assess the role of the physical and social environment in promoting health, safety, and effectiveness in the healthcare workplace, and found that the majority of the nurses agreed about the importance of the environmental risk factors tool.

\section{Application of the environmental risk factors tool}

The findings of the present study showed that El-Zohour Hospital had a higher application of the environmental risk factors than El Amery hospital. This may be due to the difference of system of administration, structures of two hospitals, as well as the presence of training center in El-Zohour hospital and who responsible for training nurses are teaching staff from nursing and medical faculties to provide continuous training for nurses about new advances in nursing, as well as, training the housekeepers regarding waste management through the following guidelines for collection of different types of health care waste, in addition to there is mechanical ventilation, and good light in the unit, good food services through there is sufficient lighting in kitchen, and workers nails are clean and shorts, continuous, frequent maintenance of equipment and the presence of plan for maintenance. These results was disagreed with Abo-El Hassan, (2011) who reported no statistically significant difference in the application of environmental risk tools was found between two studied hospitals. 


\section{CONCLUSION:}

Based on the study findings, it can be concluded that: The nurses had the highest percentage of agreement about the importance of environmental risk factors tool, while the lowest percentage of agreement among patients. Finally, the results demonstrated that the majority of environmental risk factors assessment tool where applicable, in inpatient units in two hospitals, as it more applicable in El-Zohour Hospital than Port Said General Hospital.

\section{RECOMMENDATIONS:}

1- The environmental risk factors assessment tool should be communicated for each department in health organization.

2-The environmental safety concept should be addressed by all levels of health team members and needed to be a part of staff development programs.

\section{REFERENCES:}

Abo-El Hassan, N. (2011): Designing and validating a tool to assess environmental risk factors affecting hospitalized patients. (Unpublished doctorate thesis, faculty of nursing, Ain Shams University, Egypt).

Abu Saileek, M.M. (2010): Designing and Validating Infection Control Standards for Surgical Departments at Nasser Hospital in Palestine. (Unpublished doctorate thesis, faculty of nursing, Ain Shams University, Egypt).

Association for Professional in Infection Control and Epidemiology (APIC). (2015): $2^{\text {nd }}$ edition text of infection control and epidemiology, aseptic technique- 20-2, respiratory care 63.

Barnett, P.C., Schuster (2018): Fundamentals of international occupational health

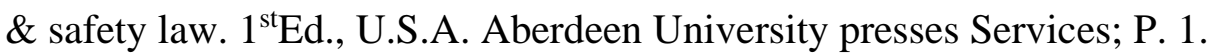

Burden, Quinn, O'Brien and Dawes, (2010):Quality assurance and risk reduction guidelines. ActaCytol. ...... Quinn MA. Adenocarcinoma of the cervix - are there arguments for a different. Available at www.cervicalcheck.ie/QAfinal- web-version. 
Carayon, P., \& Alvarado, C. J. (2017): Workload and patient safety among critical care nurses. Critical care nursing clinics of North America, 19(2), 121-129.

Centers for Disease Control and Prevention (CDC) (2010):Self-reported falls and fall-related injuries among persons aged $>$ or $=65$ years--United States, MMWR Morb Mortal Wkly Rep 2008; 57:225.

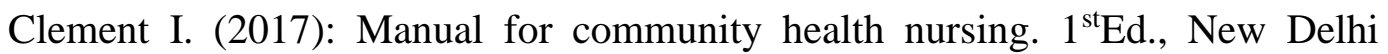
110002, India: Jypee Brothers Medical publishers (p) Ltd., Chapter 12; P. 273.

Gaber, M. (2009): Development of Risk Management Standards for Zagazig University Hospitals . Unpublished Doctorate Thesis. Faculty of Nursing, Cairo University.

George, J., Farina, (2015): Environment of Care; Hand Book. Second Edition.Joint Commission Resources. USA. New York.

Joint Commission on Accreditation of Healthcare Organizations (JCAHO) (2010):Ensuring Highest Patient Safety Standards. Http://www. Joint commission.Org.

Joint Commission on Accreditation of Healthcare Organizations (JCAHO) (2012):The Safety Checklist Program: Creating a Culture of Safety in Intensive Care Units. Volume 28, Number6

Joseph A. (2016):The impact of light on outcomes in healthcare settings. Concord, CA: Center for Health Design; Accessed at: http:// www.healthdesign.org/research/report

Landstad, B.J. ( 2016): Work environment and rehabilitation work at the hospital of Östersund - a survey of the work situation of departmental managers, Department of Health Sciences, Mid Sweden University, Östersund, Sweden

Lerche, I., \&Glaesser, W. (2016): Environmental Risk Assessment: Quantitative Measures, Anthropogenic Influences, Human Impact. Springer Science \& Business Media.

Occupational Safety \& Health Administration (2017): Health care wide hazards,

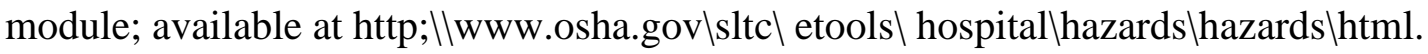


OSHA Inspection Checklist (2009):Presented by OSHA council. www.abc.org/. p. 309.

Rogers, B. (2012): Occupational and environmental health nursing. Philadelphia: Library of congress, cataloging in publication data.

Straub, J. O., \& Hutchinson, T. H. (2013): Environmental risk assessment for human pharmaceuticals: The current state of international regulations. In Human Pharmaceuticals in the Environment (pp. 17-47). Springer, New York, NY.

Tweedy, J.T. (2017): Healthcare Hazard Control and Safety Management. $2^{\text {nd }}$

Ed., Boca Raton, U.S.A: CRC Press; P. 271.

World Health Organization (WHO) (2010):World Alliance for Patient Safety Reaserch for Patient Safety, Better Knowledge for Safer Care. Available at Http:// Www.WHO.Int/PatientSafety /Research/En/.

Yoder -Wise, P. (2017): Leading and managing in nursing (4 ${ }^{\text {th }}$ Ed.) ch (19). Texas Mosby, Elsevier.289-406.

Zakzouk, H.S. (2014): Infection Control Standards in Burn Unit. Doctorate Thesis.Medical Surgical Nursing.Faculty of Nursing.Ain Shams University; 68-87.

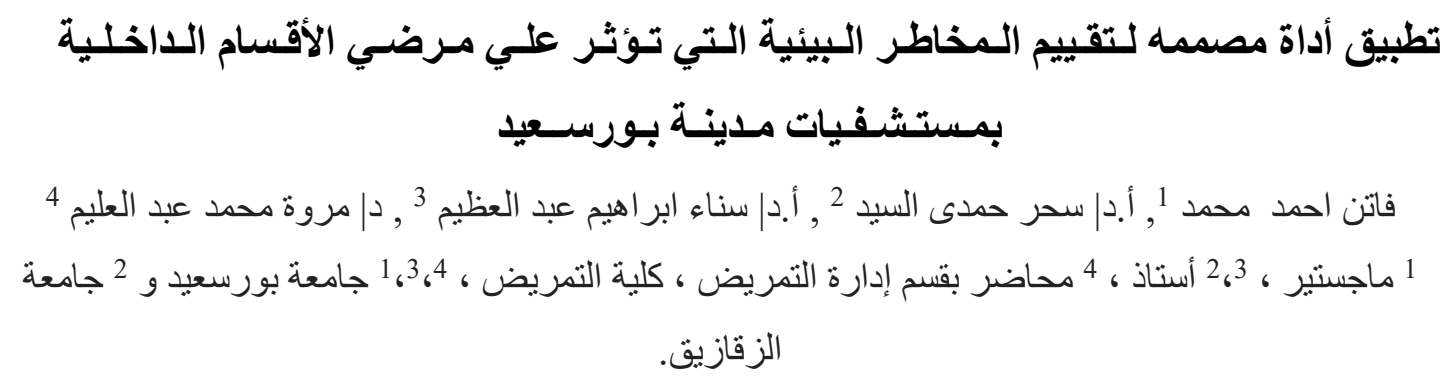

\section{الخلاصة}

تعتبر المخاطر البيئية احتمالية لحدث غير مرغوب فيه وعو اقبه تنشأ من أصل عفوي أو طبيعي أو من فعل بشري (مادي أو إداري) ينتقل عبر البيئة. تهدف هذه الدراسة الى تطبيق أداة مصممه لتقييم المخاطر البيئية التي تؤثر مئر علي مرضى الأقسام الداخلية بمستشفيات مدينة بورسعيد ـ تم تصميم دراسة منهجية ـ أجريت الدراسة في مستشفى بورسعيد العام ومستشفى الزهور. تكونت عينة الدراسة من اربعه مجموعات: جميع فريق الرعاية الصحية و عددهم 260 , جميع عمال النظافة و عددهم 39,عينة متاحة من المرضى و عددهم 60 وكذللك 35 خبير لقياس

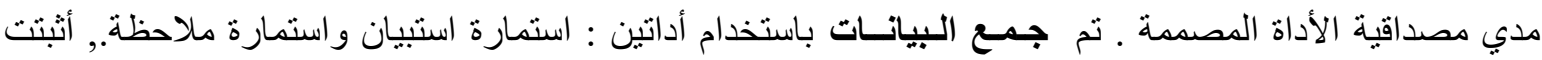


النـتـائسج ان الاداة يمكن الوثوق بها لثبات نتائج تطبيقها بو اسطة طريقه إعادة الاختبار, حيث بلغ نتائج معامل

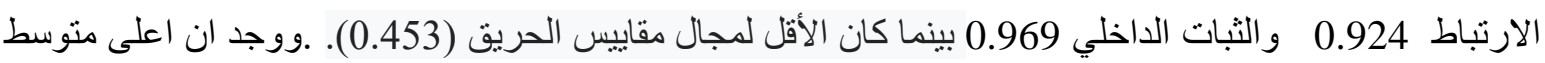
للار اء تجاه أهمية الأداة المصممة لتقييم عوامل خطورة البيئة لدى الممرضات يليه الأطباء, بينما اقل منوسط

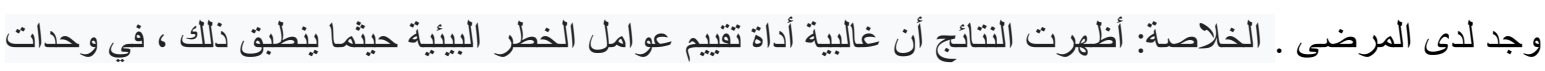
المرضى الداخليين في مستشفيين ، في حين أن أكثر قابلية للتطبيق في مستشفى الزهور من مستشفى بورسعيد العام. لذا

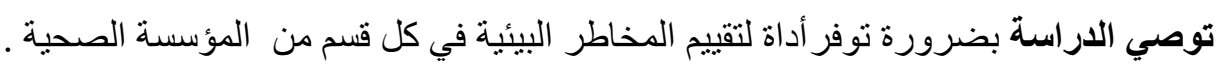
الكلمات المرشدة: الـبـئئة ، الاداه, المـــاطر ،العو امل، الــرضسى,الاطباء،التمريض 